ISSN 2620-6760, Vol.3, No. 2, Oktober 2020

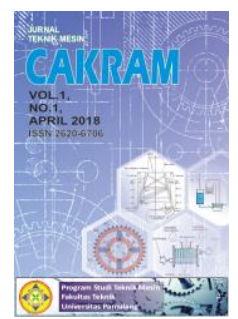

\title{
ANALISA KERUSAKAN PIPA AIR PENGUMPAN BOILER
}

\author{
Sukandar $^{1}$, Yana Heryana ${ }^{2}$ \\ ${ }^{1}$ Program Studi Teknik Mesin, Universitas Pamulang, Jl. Surya Kencana No.1, Tangerang Selatan, Indonesia \\ ${ }^{2}$ Balai Besar Teknologi Kekuatan Struktur, BPPT, Kawasan Puspiptek, Setu, Tangerang Selatan \\ E-mail : kendar.sukandar@gmail.com ${ }^{1}$, yana.heryana@bppt.go.id ${ }^{2}$
}

Masuk : 10 September 2020

Direvisi : 21 September 2020

Disetujui : 28 September 2020

\begin{abstract}
Abstrak: Pipa air pengumpan boiler adalah suatu sistem pengumpan air ke boiler. Untuk pelindungan dari serangan korosi pada pipa disuntikkan inhibitor. Kerusakan terjadi pada pipadi ujung pipa injeksi inhibitor setelah 7 tahun operasi. Lokasi pipa inhibitor adalah $800 \mathrm{~mm}$ setelah swing check valve. Untuk mencari akar penyebab dilakukan analisa kerusakan. Untuk mendukung analisa kerusakan dilakukan pengujian dan pemeriksaan komposisi kimia, fraktografi, metalografi, kekerasan, produk korosi, polarisasi, simulasi aliran dan rasio $\mathrm{Na}$ dan $\mathrm{PO}_{4}$ dalam inhibitor. Hasil pemeriksaan komposisi kimia menunjukkan bahwa material pipa adalah sesuai standar. Hasil pemeriksaan fraktografi menunjukkan kerusakan berupa penipisan lokal berbentuk cekungan sepatu kuda. Hasil pemeriksaan metalografi menunjukkan struktur mikro material pipa adalah ferit dan perlit normal. Hasil pemeriksaan produk korosi menunjukkan kandungan oksigen yang sangat tinggi. Hasil pengujian polarisansi dengan inhibitor adalah 19,991 mpy. Hasil simulasi aliran menunjukkan di lokasi pipa injeksi inhibitor adalah zona aliran diam. Hasil pemeriksaan kandungan inhibitor menunjukkan bahwa rasio $\mathrm{Na}$ dan $\mathrm{PO}_{4}$ dibawah 2,85:1. Dari hasil pemeriksaan dan pengujian tersebut dapat dikerucutkan bahwa akar penyebab kerusakan pipa air pengumpan boiler adalah serangan korosi akibat konsentrasi oksigen.
\end{abstract}

Kata kunci: Pipa Air Pengumpan Boiler, Baja Karbon, Inhibitor, Aliran Diam, Caustic Gouging, Konsentrasi Oksigen.

Abstract: Boiler feed water pipe is a water system to feed water to boiler. For corrosion protection, it is injected inhibitor. Failure took place on the pipe at location of inhibitor pipe after 7 years in operation. Location of inhibitor pipe is $800 \mathrm{~mm}$ after swing check valve. To find root cause of failure, it is conducted failure analysis. To support failure analysis, it is conducted testing and examination of chemical composition, fractography, metallography, hardness, corrosion product, polarization, fluid flow simulation, and ratio of $\mathrm{Na}$ and $\mathrm{PO}_{4}$ in inhibitor. Result of chemical composition revealed that material of pipe is in accordance with standard. Result of fractography examination revealed that failure was local thinning as a bowl of horse shoe. Result of metallography examination revealed that microstructure is ferrite and pearlite. Result of corrosion product examination revealed of oxygen high content. Result of polarization test revealed that corrosion rate with inhibitor is 19.991 mpy. Result of fluid flow simulation revealed that at the location of failure is area of stagnant flow. Result of $\mathrm{Na}_{\text {and }} \mathrm{PO}_{4}$ ratio is below 2.85:1. Results of testing and examination can be cornered that the root cause of pipe failure is corrosion attack due to cell concentration.

Keywords: Boiler Feed Water Pipe, Carbon Steel, Inhibitor, Erosion and Corrosion, Stagnant Flow, Cell Concentration 


\section{PENDAHULUAN}

Boiler adalah bagian dari proses produksi etilen di suatu industri kimia. Boiler mendapat umpan air dari jaringan sistem pengolahan air melalui pipa air pengumpan boiler (boiler feed water). Walaupun air telah diolah dan diproses sehingga menjadi air murni atau demin water, saat akan diumpan ke boiler tetap ditambahkan inhibitor, seperti ditunjukkan dalam Gambar 1. Tujuan dari penambahan inhibitor adalah untuk menambah kebasaan air pengumpan dan melapisi dinding dalam pipa sehingga mengurangi atau menghindari serangan korosi dari air pengumpan.

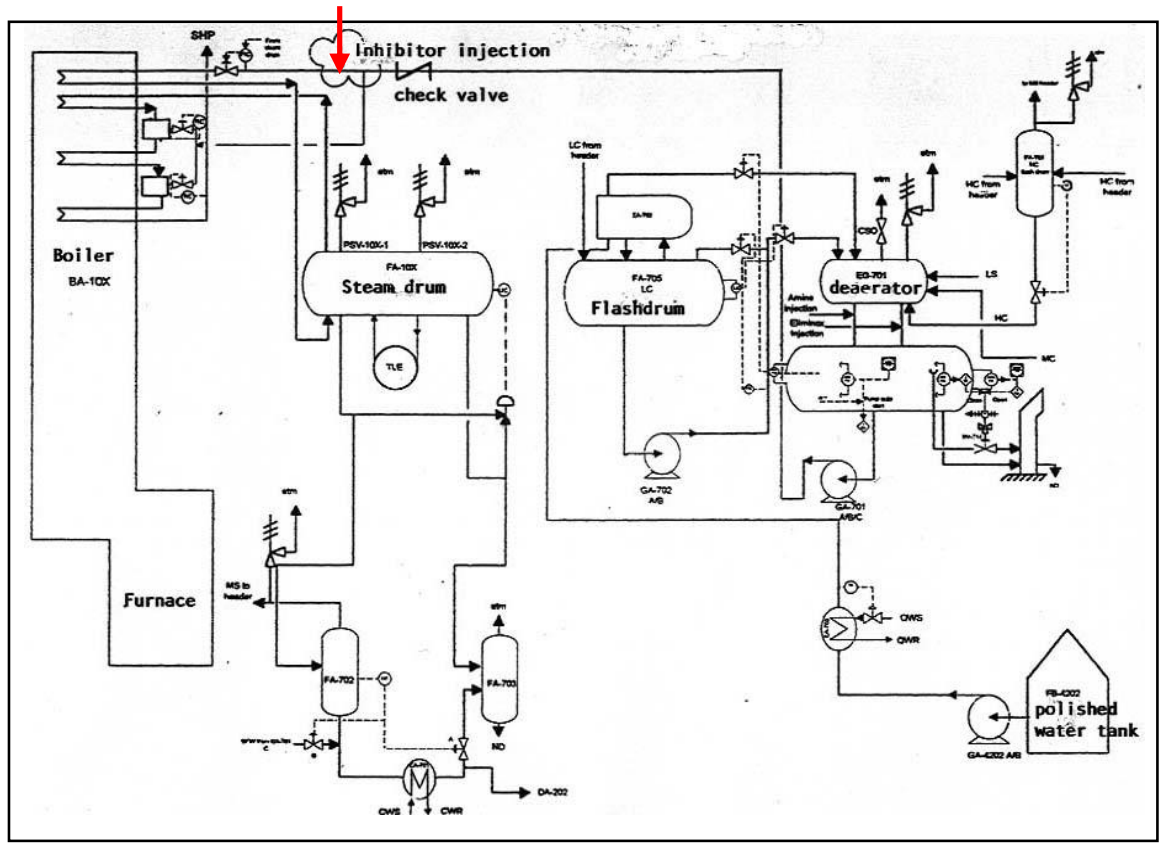

Gambar 1. Diagram jaringan sistem pengolahan air untuk umpan boiler. Sebelum diumpan ke boiler, air disuntik inhibitor melalui pipa inhibitor (panah merah).

Justru kerusakan terjadi pada ujung pipa injeksi inhibitor berupa penipisan lokal yang berbentuk cekungan dengan pola sepatu kuda (horse shoe) sehingga pipa mengalami kebocoran pada sambungan las antara pipa injeksi inhibitor dan pipa air di sisi luar. Lokasi pipa inhibitor berada $800 \mathrm{~mm}$ di belakang swing check valve. Kerusakan terjadi setelah 7 tahun operasi. Material, dimensi pipa air dan pipa inhibitor, posisi serta area kerusakan dapat dilihat pada Gambar 2.

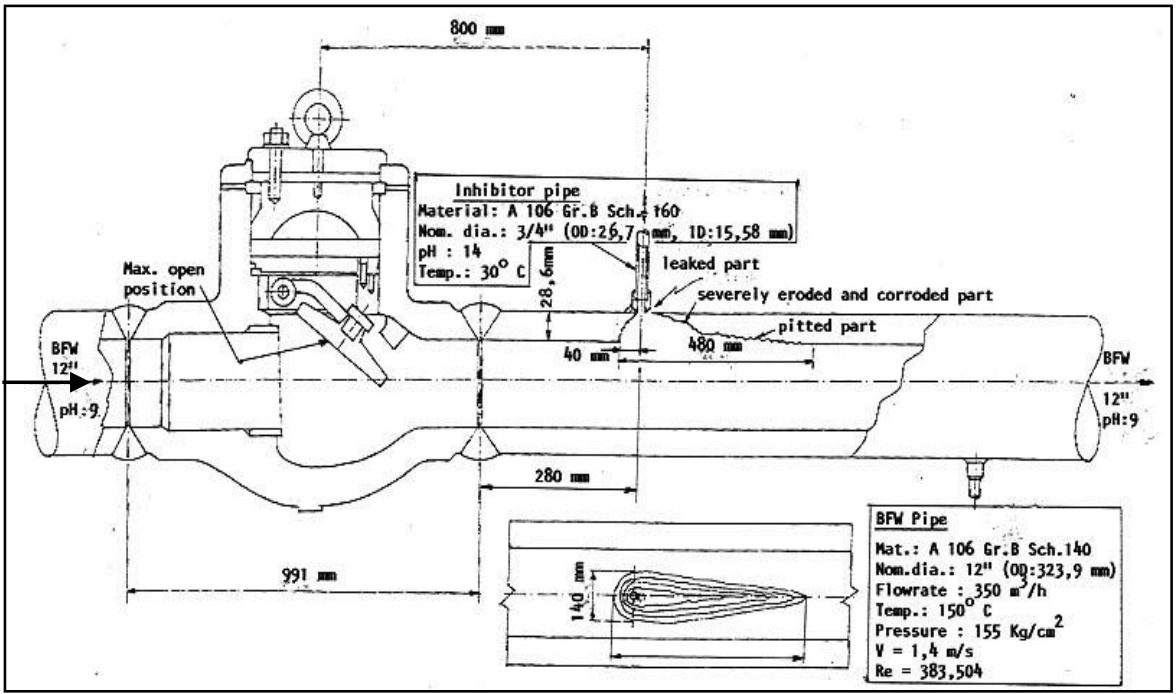

Gambar 2. Kerusakan pipa air pengumpan boiler di ujung pipa injeksi inhibitor 
Pada Gambar 2 ditunjukkan Swing Check Valve dengan besar bukaan nozzle tergantung laju aliran air. Dengan demikian sebagaimana ditunjukkan kerusakan pipa terjadi setelah air melewati Swing Check Valve.

Permukaan pipa di lokasi kerusakan ditutupi produk korosi oksida besi secara merata. Setelah lapisan produk korosi dibersihkan tampak permukaan pipa terdiri dari zona-zona seperti ditunjukkan dalam Gambar 3.

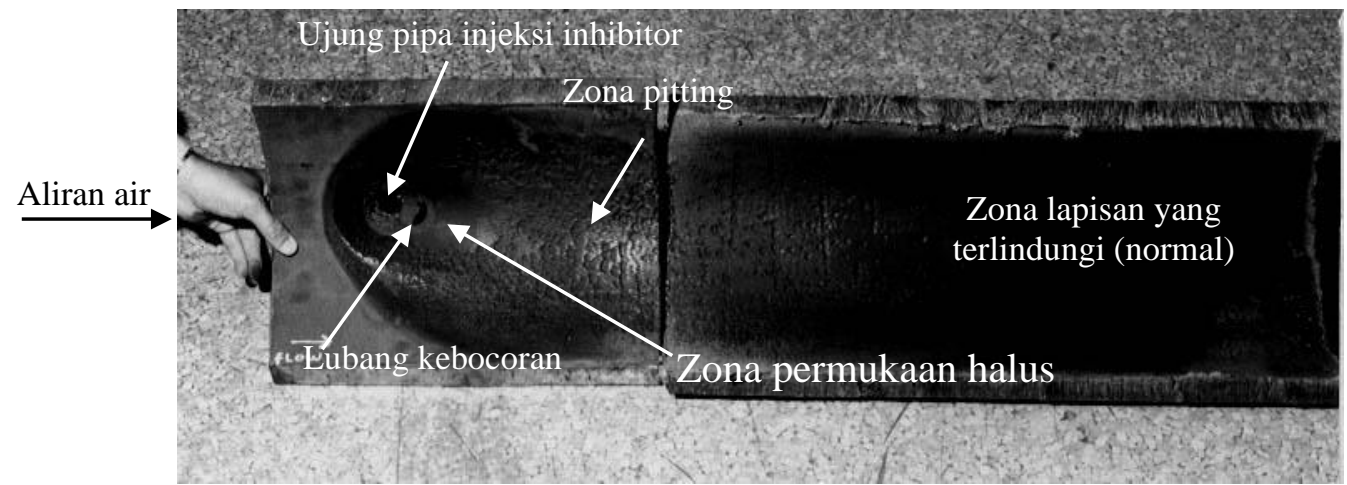

Gambar 3. Permukaan pipa air pengumpan boiler yang rusak di ujung pipa inhibitor

Berdasarkan data-data kerusakan yang terjadi pada pipa air pengumpan boiler dilakukan analisa kerusakan yang bertujuan untuk mendapatkan akar penyebab kerusakan sehingga kerusakan yang sama di masa depan dapat dihindari.

\section{METODOLOGI PENELITIAN}

1. DIAGRAM ALIR PENELITIAN

Analisa kerusakan mengikuti diagram alir penelitian seperti ditunjukkan dalam Gambar 4 .

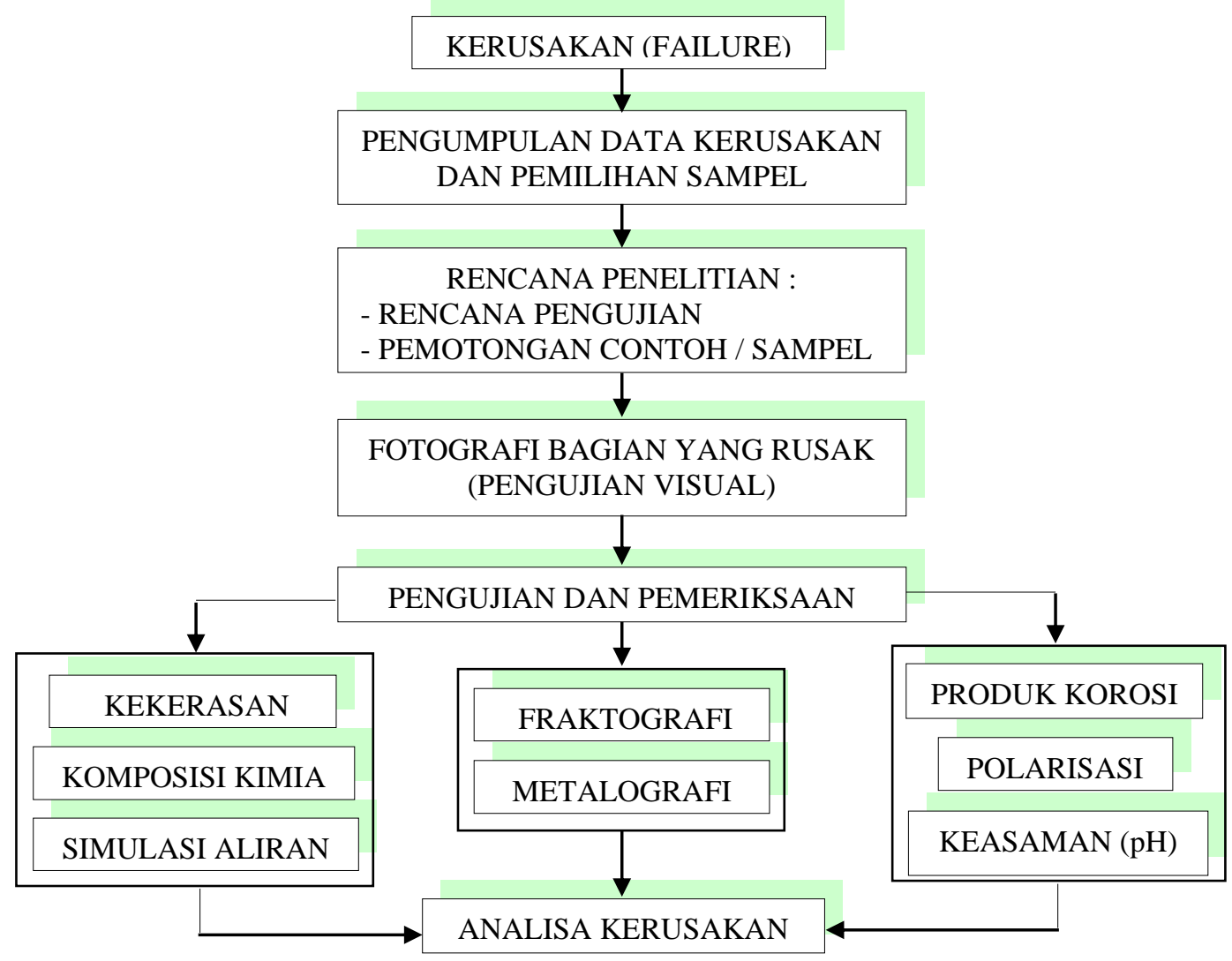

Gambar 4. Diagram Alir Penelitian

ISSN 2620-6706 


\section{DATA TEKNIS}

Pipa air pengumpan boiler yang mengalami kerusakan di ujung pipa injeksi inhibitor telah dipotong sebagai sampel untuk analis kerusakan. Data teknis dari pipa tersebut adalah sebagai berikut:
2.1 PIPA AIR
- Material
: ASTM A106 Grade B Schedule 140
- Diameter Nominal : 12 inch $(304,8 \mathrm{~mm})$
- Diameter Luar : : 12,75 inch $(323,85 \mathrm{~mm})$
- Tebal
: 1,125 inch $(28,575 \mathrm{~mm})$
- Media
: air laut yang telah diproses dan dipanaskan

\subsection{PIPA INHIBITOR}

- Material

: ASTM A106 Grade B Schedule 160

- Diameter Nominal

: 0,75 inch $(19,05 \mathrm{~mm})$

- Diameter Luar

: 1,05 inch $(26,67 \mathrm{~mm})$

- Tebal

- Media

: 0,219 inch $(5,56 \mathrm{~mm})$

: phosphate

2.3 CHECK VALVE

- Tipe

: Swing nozzle

- Material

: ASTM A105

2.4 AIR

- Temperatur $\quad: 150^{\circ} \mathrm{C}$

- Tekanan $\quad: 155 \mathrm{Kg} / \mathrm{cm}^{2}$

- Flow rate $\quad: 350 \mathrm{~m}^{3} / \mathrm{jam}$

$-\mathrm{pH} \quad: 9$

- Kandungan oksigen $\quad: 7 \mathrm{ppb}$

2.5 INHIBITOR

- Tipe $\quad: \mathrm{Na}_{3} \mathrm{PO}_{4}$ (natrium phosphate)

- Temperatur $\quad: 30^{\circ} \mathrm{C}$

- Tekanan $\quad: 160 \mathrm{Kg} / \mathrm{cm}^{2}$

- Flow rate $\quad: 0-11$ liter $/$ jam

$-\mathrm{pH} \quad: 14$

\section{PENGUJIAN DAN PEMERIKSAAN}

Pengujian dan pemeriksaan dalam analisa kerusakan ini adalah:

\subsection{PEMERIKSAAN KOMPOSISI KIMIA}

Pemeriksaan komposisi kimia dilakukan untuk mengetahui unsur-unsur yang dikandung dalam material pipa dan mencocokkannya dengan spesifikasi standar ASTM A106 grade B. Alat yang digunakan adalah Spark Spectrometer Metorex.

\subsection{PEMERIKSAAN FRAKTOGRAFI DAN METALOGRAFI}

Pemeriksaan fraktografi dilakukan untuk mengamati mode kerusakan di permukaan pipa yang mengalami kerusakan. Pemeriksaan metalografi dilakukan untuk mengamati struktur mikro dan cacatcacat mikro yang bisa membantu menunjukkan mekanisme awal kerusakan.

3.3 PENGUJIAN KEKERASAN

Pengujian kekerasan dilakukan untuk mengetahui nilai kekerasan pipa. Perubahan nilai kekerasan akibat operasi bisa diketahui dengan uji kekerasan ini. Nilai kekerasan hasil uji juga dibandingkan dengan nilai standar ASTM A106 grade B. Alat yang digunakan adalah Hardness Tester Frank Finotest.

\subsection{PEMERIKSAAN PRODUK KOROSI}

Pemeriksaan produk korosi dilakukan pada permukaan pipa yang terserang korosi untuk mengetahui visual 
permukaan pipa secara mikro, dan kandungan unsur-unsur pada produk korosi tersebut. Alat yang digunakan adalah SEM-EDS (Scanning Electron Microscope - Energy Dispersion Spectrometer) JEOL.

\subsection{PEMERIKSAAN POLARISASI}

Pengujian polarisasi dilakukan dengan Corrosion Measurement System (CMS) untuk mengetahui laju korosi yang dialiri air pengumpan boiler dan inhibitor pada kondisi laminar.

\subsection{PENGUJIAN SIMULASI ALIRAN}

Simulasi aliran dilakukan dengan Computational Fluid Dynamics (CFD) Phoenics untuk mendapatkan gambaran pola aliran pada pipa air pengumpan boiler. Model dibuat sesuai dengan dimensi pipa,air pengumpan boiler, posisi check valve dan pipa injeksi inhibitor dan kondisi operasi aliran.

\subsection{PEMERIKSAAN KEASAMAN $(\mathrm{pH})$}

Pemeriksaan keasaman dilakukan dengan memeriksa rasio antara $\mathrm{Na}$ dan $\mathrm{PO}_{4}$ berdasar teori Purcell and Whirl. Menurut Purcell and Whirl reaksi antara inhibitor dan air bisa menimbulkan konsentrasi basa yang disebut caustic gouging (korosi caustic) apabila rasio antara $\mathrm{Na}$ dan $\mathrm{PO}_{4}$ melebihi 2,85 : 1 .

\section{HASIL DAN PEMBAHASAN}

\section{HASIL PENGUJIAN DAN PEMERIKSAAN}

\subsection{KOMPOSISI KIMIA}

Hasil pemeriksaan komposisi kimia pipa air disajikan dalam Tabel 1.

Tabel 1. Hasil pemeriksaan komposisi kimia piap air

\begin{tabular}{lcccccc}
\hline & Fe & C & Si & Mn & P & S \\
\hline Pipa air (\% berat) & 98,89 & 0,14 & 0,15 & 0,80 & 0,0042 & 0,021 \\
ASTM A106B & Sisa/unsur dasar & 0,30 maks. & 0,10 min. & $0,29-1.06$ & 0,048 max. & 0,058 max \\
\hline
\end{tabular}

Hasil pemeriksaan komposisi kimia pada pipa air menunjukkan bahwa spesifikasi material pipa air sesuai dengan standar ASTM A106 grade B

\subsection{FRAKTOGRAFI}

Hasil pemeriksaan fraktografi atau visual pada permukaan pipa air menunjukkan cekungan pola sepatu kuda dengan dimensi $480 \mathrm{~mm}$ panjang dan $140 \mathrm{~mm}$ lebar pada sisi dalam pipa dan lubang kebocoran di sambungan las antara pipa injector inhibitor dan pipa air sisi luar seperti sudah ditunjukkan dalam Gambar 2. Dengan arah aliran dari sisi swing check valve, cekungan terdalam terjadi pada ujung pipa injector inhibitor dengan permukaan halus dan kemudian diikuti oleh permukaan yang berlubang-lubang (Gambar 3).

\subsection{KEKERASAN}

Hasil pengujian kekerasan disajikan dalam Tabel 2.

Tabel 2. Hasil pengujian kekerasan

\begin{tabular}{|c|c|c|c|c|c|c|}
\hline & 1 & 2 & 3 & 4 & 5 & Rata-rata \\
\hline Kekerasan (HV) & 148 & 135 & 135 & 135 & 135 & 138 \\
\hline
\end{tabular}

ASTM A106 tidak mencantumkan persyaratan nilai kekerasan. Yang dicantumkan adalah persyaratan nilai tegangan tarik, yaitu minimum $415 \mathrm{~N} / \mathrm{mm}^{2}$, yang dikonversi ke kekerasan adalah minimum $130 \mathrm{HV}$. Karena hasil pengujian kekerasan adalah $138 \mathrm{HV}$, material pipa sesuai atau masih sesuai dengan standar. 


\subsection{METALOGRAFI}

Hasil pemeriksaan metalografi menunjukkan bahwa struktur mikro pipa di lokasi yang mengalami kerusakan adalah ferlitdan ferit normal, tidak tampak perubahan struktur maupun cacat proses, dan tidak ditemukan cacat operasi, seperti ditunjukkan dalam Gambar 5.

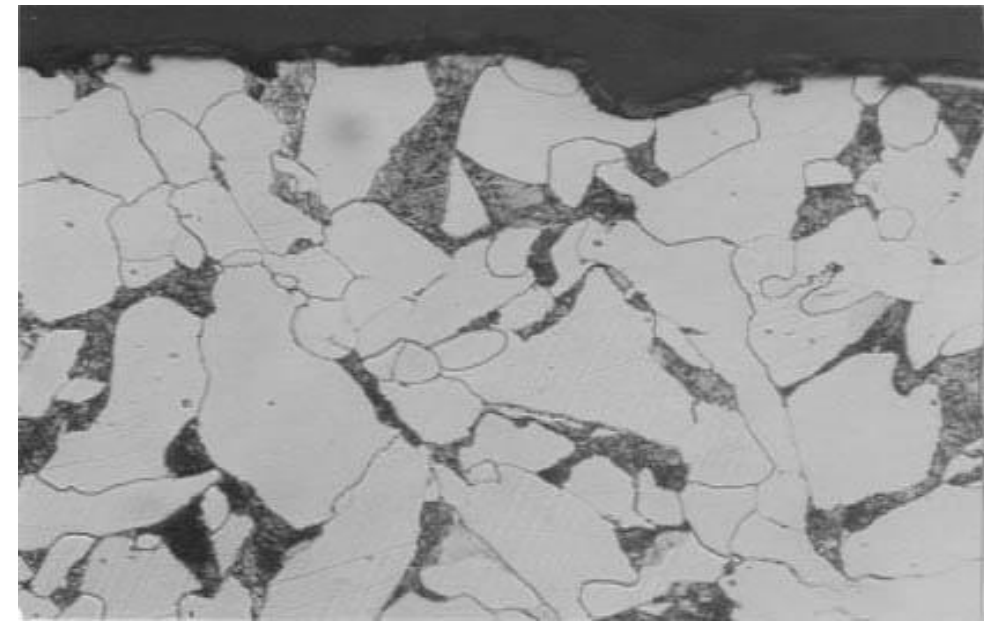

Gambar 5. Struktur mikro pipa, perbesaran 200X

\subsection{PRODUK KOROSI}

Pemeriksaan produksi korosi dilakukan dengan SEM-EDS.Hasil pemeriksaan SEM menunjukkan kerak-kerak produk korosi di permukaan pipa yang mengalami kerusakan seperti ditunjukkan dalam Gambar 6 .

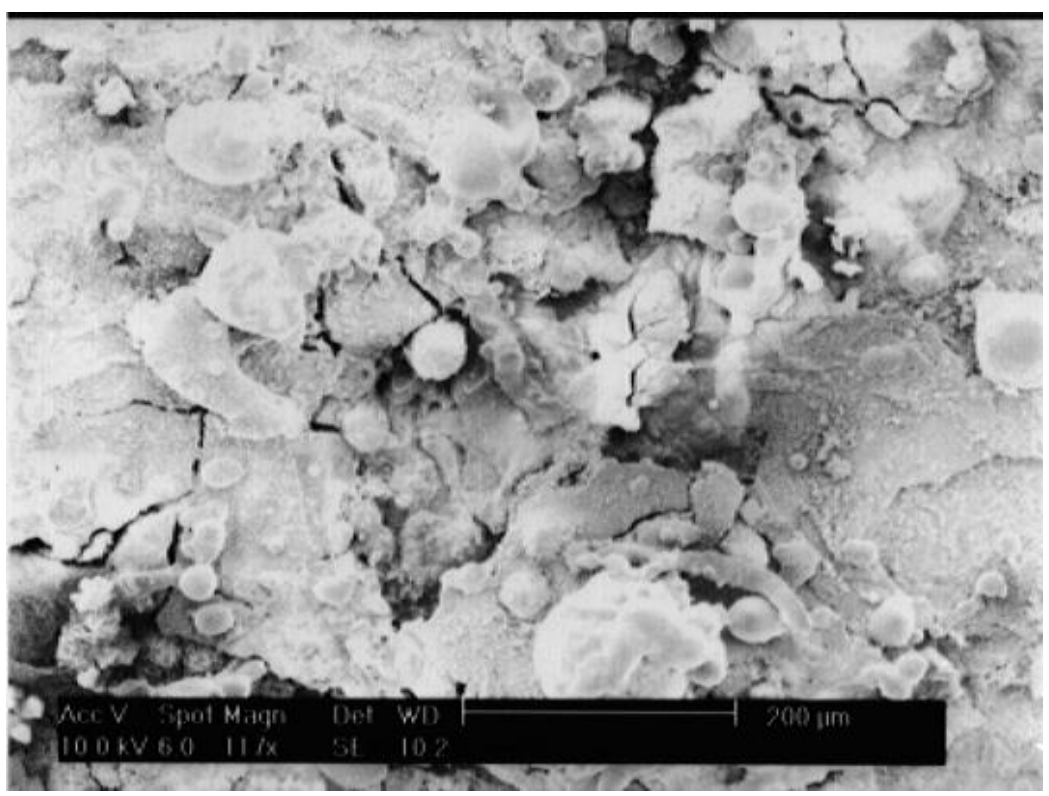

Gambar 6. Kerak-kerak produk korosi di permukaan pipa

Hasil pemeriksaan EDS menunjukkan kandungan unsur-unsur yang terdapar pada produk korosi dengan kandungan oksigen (O) yang tinggi, yaitu 38,28 \% berat, seperti ditunjukkan dalam Gambar 7. 

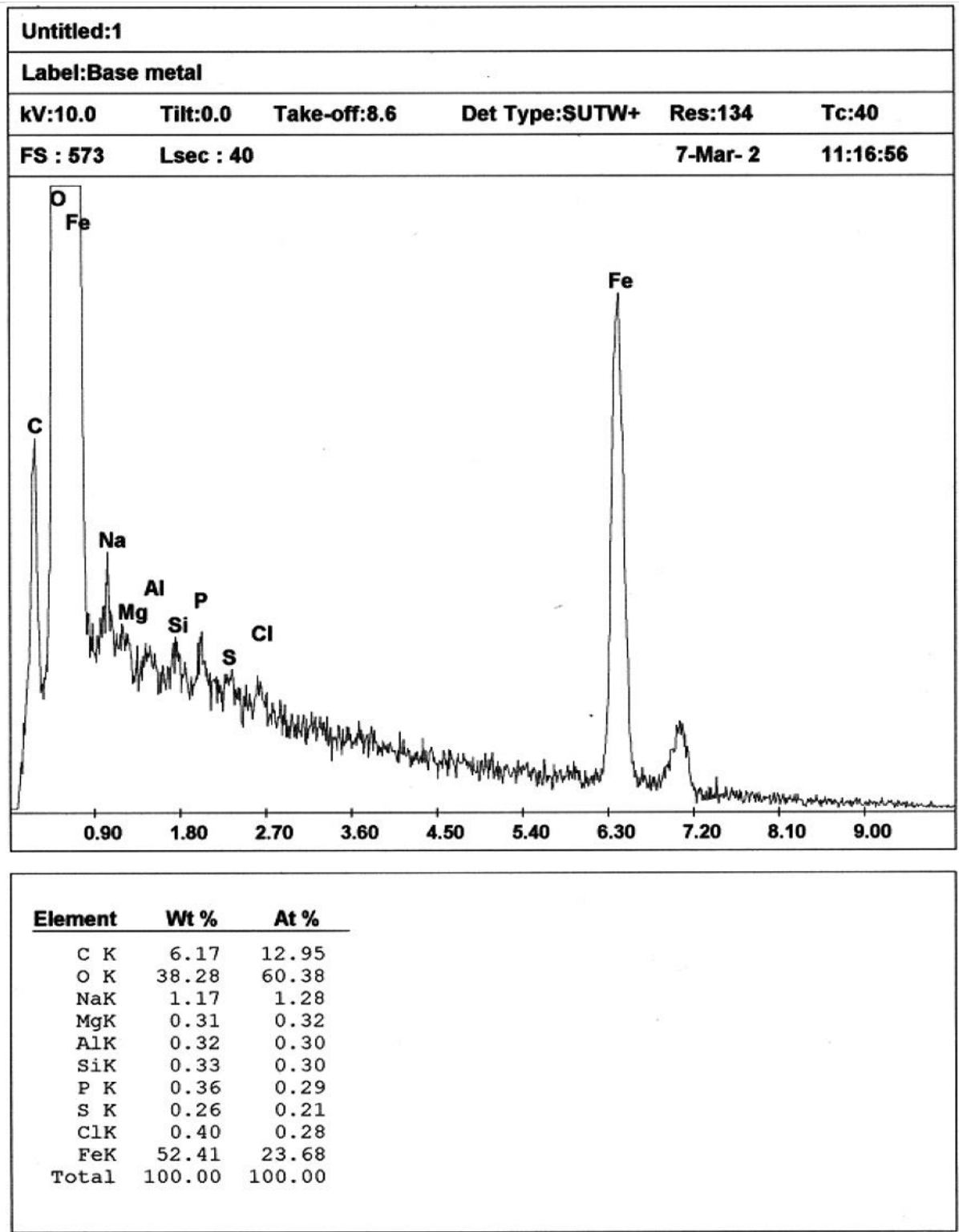

Gambar 7. Hasir pemeriksaan EDS menunjukkan kandungan unsur-unsur pada produk korosi

\subsection{POLARISASI}

Hasil pengujian polarisasi menunjukkan bahwa laju korosi pada pipa dengan air tanpa inhibitor adalah 28,383 mpy (0,721 mm/tahun), sedangkan laju korosi pada pipa dengan air dengan inhibitor adalah 19,991 mpy (0,508 $\mathrm{mm} / \mathrm{tahun}$ ) seperti dapat dilihat pada Gambar 8 dan 9. 
Sukandar dan Yana Heryana, Analisa Kerusakan Pipa Air Pengumpan Boiler

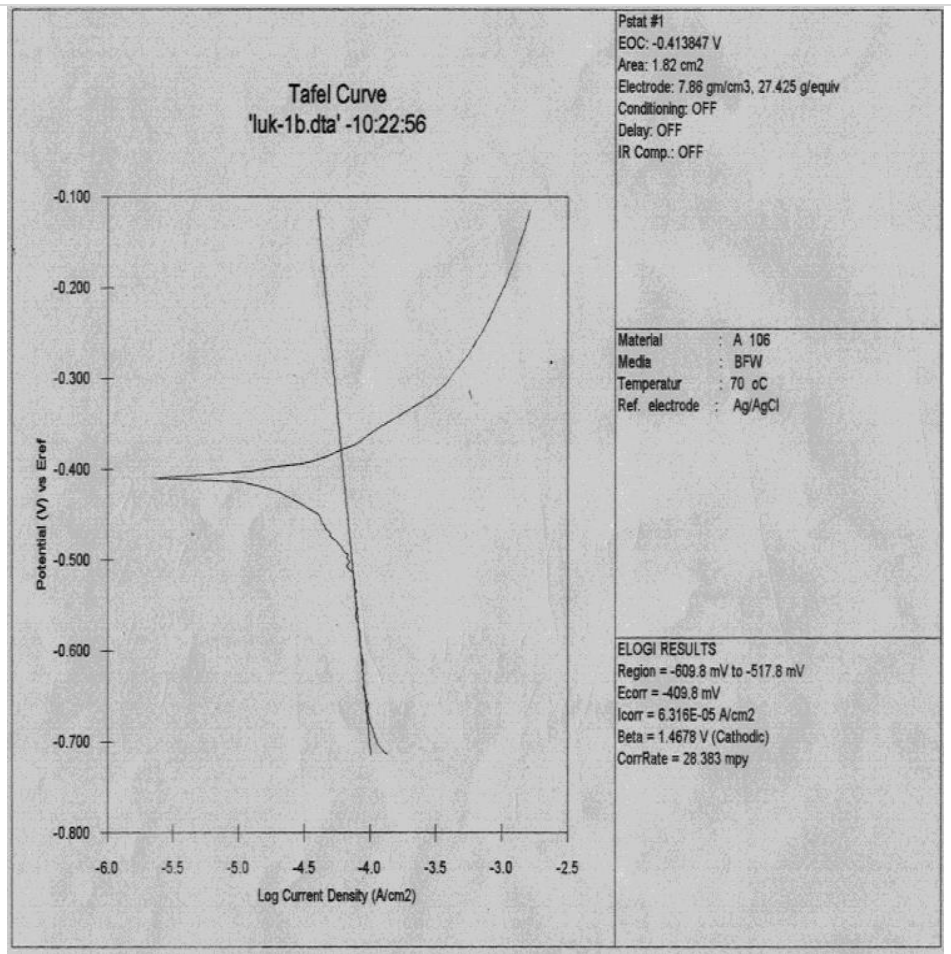

Gambar 8. Hasil pengujian polarisasi dengan air tanpa inhibitor

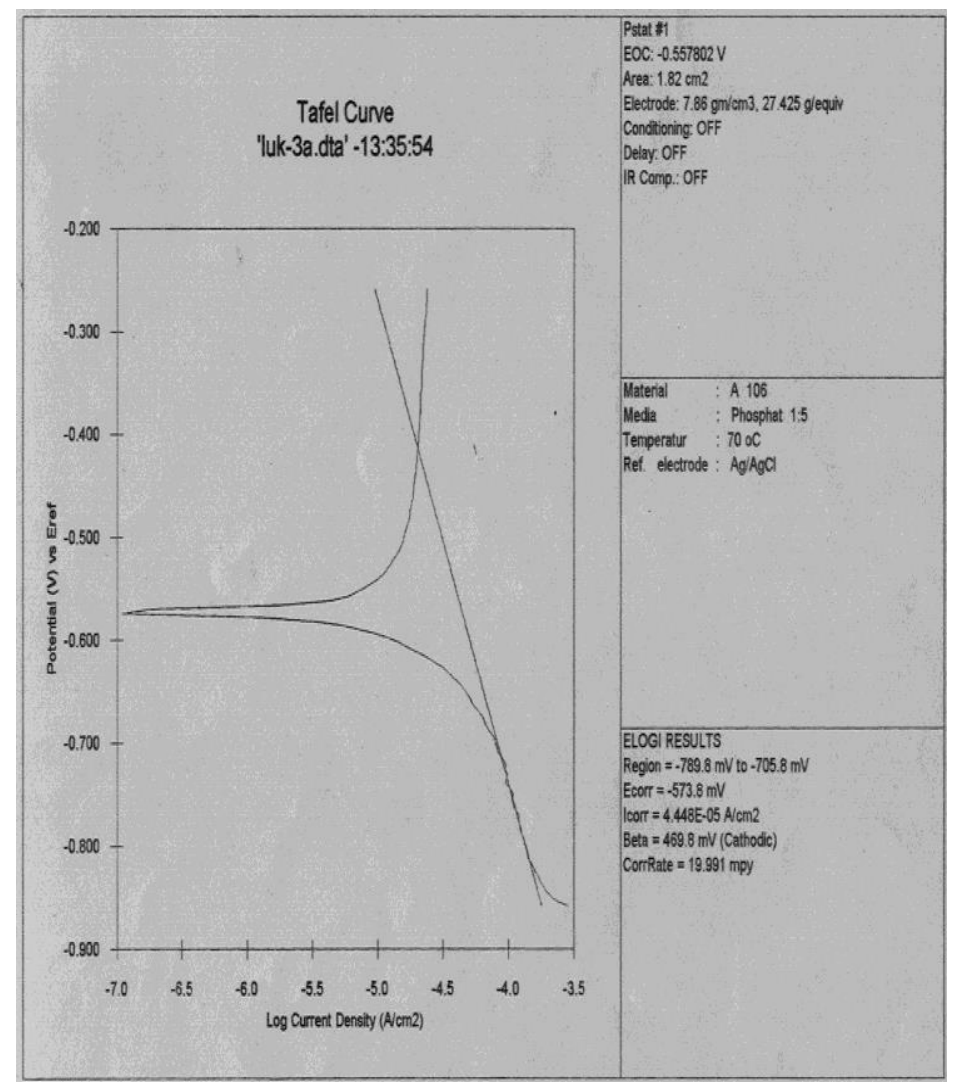

Gambar 9. Hasil pengujian polarisasi dengan air dengan inhibitor 


\subsection{SIMULASI ALIRAN}

Hasil simulasi aliran menunjukkan bhwa di area yang mengalami kerusakan berada pada zona aliran diam seperti ditunjukkan dalam Gambar 10.

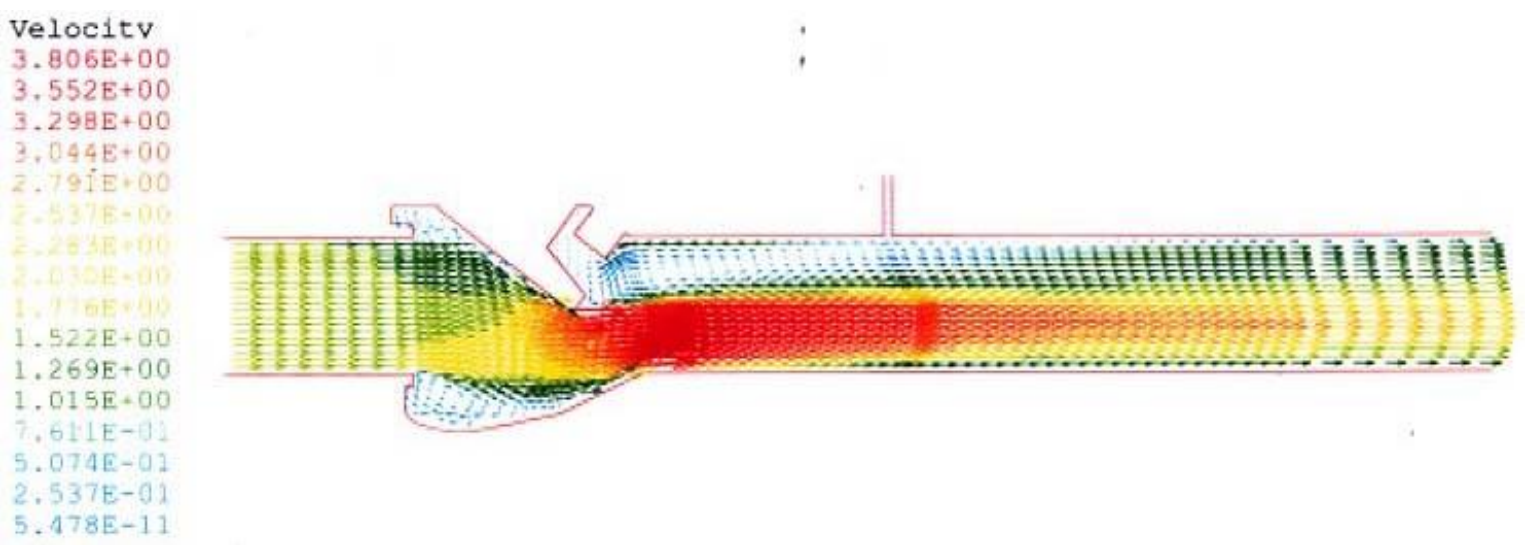

Gambar 10. Hasil simulasi aliran menunjukkan zona aliran diam di ujung pipa injector inhibitor

\subsection{RASIO Na dan $\mathrm{PO}_{4}$}

Hasil pemeriksaan rasio antara $\mathrm{Na}$ dan $\mathrm{PO}_{4}$ diperoleh dari produsen inhibitor. Berdasarkan informasi dari produsen inhibitor, rasio $\mathrm{Na}$ dan $\mathrm{PO}_{4}$ dalam inhibitor adalah dibawah 2,85 : 1 .

\section{PEMBAHASAN}

Hasil pemeriksaan fraktografi membuktikan bahwa kerusakan pipa air terjadi di lokasi pipa inhibitor dengan bentuk cekungan sepatu kuda berdimensi $140 \mathrm{~mm}$ lebar dan $480 \mathrm{~mm}$ panjang dengan lobang kebocoran di lasan pipa inhibitor dan pipa sisi luar (lihat Gambar 3). Penyebab dari kerusakan ditentukan oleh hasil pengujian dan pemeriksaan dibawah ini.

Hasil pemeriksaan komposisi kimia (lihat Tabel 1) dan pengujian kekerasan (lihat Tabel 2) terhadap pipa air pengumpan menunjukkan bahwa material pipa sesuai dengan standar ASTM A106 grade B. ${ }^{[1]}$ Hasil ini memastikan tidak ada kesalahan dalam pemilihan material. Maka pemilihan material bukan lah penyebab kerusakan.

Hasil pemeriksaan metalografi (lihat Gambar 5) menunjukkan bahwa struktur mikro pipa adalah ferit dan perlit dengan kondisi normal dan tidak ditemukan cacat dan/atau perubahan struktur. ${ }^{[2]}$ Dengan demikian parameter operasi yang diterapkan pada pipa air sebagai penyebab kerusakan bisa disingkirkan.

Hasil pengujian polarisasi menunjukkan laju korosi pada pipa dengan air tanpa inhibitor (lihat Gambar 8) adalah 28,383 mpy atau 0,721 mm/tahun, yang berarti 5,047 mm penipisan akibat korosi dalam 7 tahun. Hasil pengujian polarisasi dengan air dan inhibitor (lihat Gambar 9) adalah 19,991 mpy atau 0,508 mm/tahun, yang berarti 3,556 mm penipisan akibat korosi dalam 7 tahun. Karena tebal pipa $7 \mathrm{~mm}$ maka serangan korosi oleh air, baik tanpa maupun dengan inhibitor, bisa disingkirkan sebagai penyebab kerusakan. ${ }^{[3]}$

Hasil simulasi aliran (lihat Gambar 10) menunjukkan bahwa di lokasi pipa inhibitor merupakan zona aliran diam, yang berarti kerusakan pipa sebagai erosi aliran turbulen bisa disingkirkan. ${ }^{[4]}$

Hasil pemeriksaan rasio $\mathrm{Na}$ dan $\mathrm{PO}_{4}$ pada inhibitor menunjukkan bahwa rasio $\mathrm{Na}$ dan $\mathrm{PO}_{4}$ dibawah 2,85:1. Ini berarti kerusakan pipa akibar konsentrasi basa bisa disingkirkan. ${ }^{[5,6]}$

Hasil pemeriksaan produk korosi (lihat Gambar 7) menunjukkan kandungan oksigen yang tinggi pada produk korosi. Ini berarti oksigen unsur dominan dalam senyawa produk korosi. Dengan demikian ini menunjukkan konsentrasi oksigen sebagai penyebab kerusakan pipa. Ini didukung oleh pengamatan pada tangka inhibitor yang terbuka. Namun demikian, lokasi pipa inhibitor yang berada di zona aliran diam memberi kontribusi utama pada konsentrasi oksigen ini ${ }^{[7]}$. 


\section{KESIMPULAN}

Dari hasil pengujian dan pemeriksaan dapat disimpulkan bahwa penyebab kerusakan pipa air pengumpan boiler adalah kombinasi dari lokasi pipa inhibitor dan tangki inhibitor yang terbuka, yang menyebabkan terjadinya konsentrasi oksigen (cell concentration) di ujung pipa inhibitor. Untuk menghindari kerusakan yang sama disarankan pipa inhibitor ditempatkan pada jarak $1500 \mathrm{~mm}$ atau lebih dari swing check valve, dan tangki inhibitor ditutup.

\section{DAFTAR PUSTAKA}

[1] .........., 2004, Annual Book of ASTM Standards, Part 1 : Piping, Tubing, Fitting Steel, ASTM, USA.

[2] Pridgeon, J.W., et. al, 2004, Metallography and Microstructures, ASM Handbook Volume 9, ASM International, USA.

[3] Prozhega, M.V., et. al, 2014, Experimental study of erosion-corrosion wear of materials, Journal of Friction and Wear 35, p. 155-160.

[4] Souissi, F., et. al, 2019, The flow structure in the narrow gaps of compound channels: a linear stability analysis, International Journal of Computational Fluid Dynamics, Volume 34, Issue 1.

[5] Setaro, D.M., 2006, Considerations for High Pressure Boiler Chemical Treatment - Equipment and Chemistry, Ammonia Technical Manual, GE Water and Process Technology.

[6] Baghni, I.M., et. al., 2009, Using of congruent phosphate as equilibrium phosphate boilers water treatment, WIT Transactions on The Built Environment, Vol. 110.

[7] Jafar, S.A., et. al., 2015, Reducing of Corrosion Rate in Boiler Tubes Using Oxygen Scavengers, Iraqi Journal of Chemical and Petroleum Engineering, Vol. 16 No. 4, p. 21 - 29. 